\title{
Health research in the developing world: A gastroenterological view from Bangladesh
}

\author{
J RICHARD HAMILTON MD
}

JR HAmilton. Health research in the developing world: A gastroenterological view from Bangladesh. Can J Gastroenterol 1997;11(1):94-98. Ill health is a serious impediment to progress in most poor countries, yet health is not a high priority on foreign aid agendas. Health research, which provides the essential base for sustainable progressive health programs, is barely visible in developing countries. For example, in Bangladesh, one finds unacceptably high morbidity and mortality rates among infants and children, health programs that are struggling and a rudimentary health research establishment; for the huge foreign donor community in that country, health programs and research do not appear to warrant major investments. Diarrheal diseases are at the top of the list of killers in many poor nations including Bangladesh. Recent advances in our understanding of diarrhea suggest that while prevention may not be possible soon, improved active treatment can evolve from an aggressive research effort centred in a developing country and linked to appropriate international partners. Global agencies such as the World Health Organization have demonstrated a declining interest in health research, as reflected in the policies of their Diarrhoeal Disease Control Programme. Major donors to the developing world, the Canadian International Development Agency for example, have had a relatively minor involvement in health and little commitment to health research. University links with the west, private enterprises and specially targeted programs are involved in developing world health research but they have not been able to foster and leave behind sustainable, high quality research programs. The problem should be attacked directly by supporting focused, relevant health research centres in regions of the world where the burden of disease continues to impede progress and where the environment is conducive to high quality research that is well integrated with care delivery programs. An instructive model of this approach is the International Centre for Diarrhoeal Disease Research in Dhaka, Bangladesh.

Key Words: Development aid, Diarrheal diseases, Health research, Oral rehydration

La recherche sur la santé dans les pays en voie de développement : gastro-entérologie au Bangladesh

RÉSUMÉ : Les problèmes de santé sont un grave obstacle au progrès dans la plupart des pays en voie de développement et pourtant, la santé n'est pas une grande priorité dans les programmes d'aide internationale. La recherche sur la santé, qui forme la base des programmes sanitaires progressifs viables, est rarement visible dans les pays en voie de développement. Par exemple, au Bangladesh, on trouve des taux inacceptables de morbidité et de mortalité chez les nourrissons et les enfants, des programmes sanitaires qui luttent pour se maintenir à flot et des établissements rudimentaires pour la recherche en santé; pour le fort contingent de coopérants étrangers en poste dans ce pays, les programmes sanitaires et la recherche en santé se semblent pas justifier d'investissements. Les maladies diarrhéiques sont les principales causes de décès dans de nombreux pays pauvres, y compris au Bangladesh. Les récents progrès accomplis dans le domaine de la gastro-

voir page suivante

This paper was part of a symposium entitled 'Selected topics in pediatric gastroenterology and nutrition' held in October 1995 to honour the academic career of Dr Gordon G Forstner

Department of Pediatrics, McGill University and The Montreal Children's Hospital, Montreal, Quebec; and Clinical Sciences Division, International Centre for Diarrhoeal Disease Research, Dhaka, Bangladesh

Correspondence: Dr JR Hamilton, Montreal Children's Hospital, 2300 Tupper Street, Montreal, Quebec H3H 1P3. Telephone 514-934-4467, fax 514-989-3751 
entérologie, donnent à penser que si l'application de programmes de prévention est encore loin, l'amélioration des thérapeutiques actives pourrait évoluer à partir de travaux de recherches dynamiques centrés dans les pays en voie de développement en collaboration avec les partenaires de la communauté internationale. Les agences centrales, comme l'Organisation mondiale de la santé ont manifesté un intérêt décroissant à l'endroit de la recherche en santé, comme en font foi les politiques de son programme de lutte contre les maladies diarrhéiques. Les champions de la coopération internationale, comme l'Agence canadienne de développement international par exemple, ont relativement peu participé aux programmes sanitaires et à la recherche en santé. Les liens universitaires avec l'Occident, l'entreprise privée, et surtout les programmes spécialisés, s'occupent de recherche en santé dans le tiers-monde, mais se sont révélés incapables de promouvoir des programmes de recherche de grande qualité et de les rendre viables. Il faut attaquer le problème de front en soutenant les centres qui travaillent à des projets de recherche spécifiques, pertinents et viables, dans des régions du globe où le fardeau imposé par la maladie continue d'entraver le progrès et où les conditions sont propices à une recherche de qualité qui soit bien intégrée aux programmes de prestation des soins. L'International Centre for Diarrhoeal Disease Centre de Dhaka, au Bangladesh est un modèle du genre.
$\mathrm{T}$ wenty-five years have passed since the first demonstration of the remarkable benefits of rational oral rehydration therapy (ORT) for patients with dehydrating diarrhea. Celebrations of this silver anniversary have pointed with justified pride to the impact of the World Health Organization (WHO)/United Nations Children's Fund (UNICEF) global program for the promotion, distribution and use of ORT. Termed the medical advance of the century (1), this simple, inexpensive measure has been credited with substantial reductions in morbidity and mortality from diarrhea (2).

The current formulation of the WHO/UNICEF oral rehydration solution (ORS) is based on knowledge of the basic transport derangement identified for cholera diarrhea 30 years ago. With roughly equimolar concentrations of sodium and glucose, the solution is designed to take advantage of an intact intestinal brush border absorptive surface and to maximize water uptake in the face of a potent secretory drive in the gut. These assets are well substantiated by therapeutic results in cholera (3) and other similar diseases. Theoretically, the composition of the current solution has fewer assets for noncholera diarrhea states, by far the most common of which is rotavirus diarrhea. Here the loss of mature absorptive function is expected to limit intestinal capacity to absorb solute and water (4). In fact, clinical trials have indicated that the WHO/UNICEF ORT can be used effectively and safely to rehydrate most infants and children with rotavirus diarrhea (5).

However, despite a massive, aggressive, well organized programmatic approach to promote ORS, 25 years later its use and acceptance remain surprisingly low. In Southeast Asia, the world's capital of diarrhea and the region where the ORT story began, it is estimated that only about half of the $80 \%$ of the population with access to the solution use it for treating diarrhea. On a smaller scale, turning to Rwanda, recent experience with serious cholera and shigella epidemics in refugee camps revealed extraordinarily high mortality rates and a surprising unfamiliarity with or resistance to the use of conventional ORT among the health care professionals involved in this crisis (6).

A feature of ORT treatment limiting its widespread acceptance seems to be its propensity to worsen diarrhea, particularly in cases of noncholera diarrhea. In rotavirus enteritis, which accounts for up to $40 \%$ of cases in children, this increase in stool output is understandable given the lim- ited absorptive capacity of the affected gut and the relatively high, hyperosmolar concentrations of ORS solutes, including glucose, that can overload the gut's capacity to transport them. Every mother knows that if her child is given something for diarrhea and the diarrhea worsens, the treatment cannot be any good - never mind that it has saved the baby from fatal dehydration!

Effective prevention is not on the immediate horizon and new, active treatment strategies are needed. With all the other health priorities of the developed world, modern relevant research will have to emanate, in part at least, from the developing world. Before discussing these issues and some possible solutions from a developing world perspective, it is useful to summarize our current understanding of the pathophysiological mechanisms of diarrhea as a basis for the concept that improvements in treatment might be anticipated.

\section{MECHANISMS OF DIARRHEA}

Significant progress has been made in the past decade, particularly in the unravelling of the complexities of intestinal secretory processes and their regulation. These advances include the molecular definition of the sodium-glucose cotransporter, $\mathrm{Na}^{+} / \mathrm{H}^{+}$antiports and the $\mathrm{Cl}^{-}$ion channel CFTR $(7-10)$. These discoveries have opened new experimental approaches to the study of gut function and regulation through genetic manipulation and a range of specific inhibitors. The cell matrix and its surface configuration are sensitive to a range of regulating factors and can determine transport function (11). We now recognize the important impact of cellular and neural components of the subepithelium on secretory function in the gut. The cellular infiltrations associated with infections and inflammatory disorders causing diarrhea in humans can have a major effect on secretion (12). Not all the pathways for these interactions are known, but the involvement of several factors, including neurotransmitters, is understood. The enteric nervous system is now accepted as an important player in intestinal secretion through its actions on the epithelium and subepithelial cells (13).

Preventive strategies against major enteric infections are being worked on. Progress has been made, but it will be some time before public health programs will have effective, safe vaccines on a scale that can significantly reduce the incidence of serious, potentially fatal acute diarrhea. In the 
meantime, can more be done to improve active treatment? Do advances in the laboratory provide a basis for better practical treatment measures? My answer is a qualified 'yes'. The ORS formulation could be improved. No new proven pharmacological interventions to deal with gut secretion in humans are at hand, but new knowledge of the many steps involved in that secretory process and a better understanding of the complex array of regulating factors involved permit us to contemplate pharmacological interventions. The array of new technology available to study these phenomena gives one some expectation that a concerted scientific attack could yield practical benefits. To consider how such an initiative involving developing world scientists might be mobilized, I will focus on one country, Bangladesh, and the current status of health research and research support in that country as examples for consideration.

\section{HEALTH STATUS IN BANGLADESH}

One of the world's poorest countries, Bangladesh has a population of 220 million living in an area about the size of New Brunswick. With an ancient Bengali culture and an extensive university system, the country has many assets. Impressive progress has been made in controlling birth rate, which has decreased over the past decade from approximately seven children per mother to three (14). The quality of the public educational system leaves much to be desired but now more than $70 \%$ of boys and girls are in school at the junior levels. Life expectancy has reached 60 years and women now are expected to live longer than men. Child and infant mortality rates have decreased in the past 10 years but they remain unacceptably high at $113 / 10,000$ and $86 / 10,000$ respectively $(15,16)$. A major cause of that mortality is diarrheal disease, despite the availability of clean water to most people, extensive use of breast-feeding, efforts to promote hygienic practices such as hand cleansing and promotion of ORT. Clearly, it is highly desirable to reduce this high mortality rate. Improved child survival would be expected to lead to a reduced birth rate and a healthier population base, essential for economic progress.

Consumed by the need to deal directly with the prevention and treatment of a huge disease burden, Bangladesh has not yet placed significant resources in a research base to support its health programs. There are three main agencies concerned with research in Bangladesh including the Bangladesh Medical Research Council, but the funds disbursed to support research through these agencies are less than US $\$ 2$ million per year. Most of the meagre resources available for health research programs from international and national sources have been directed to needed public health education.

There is a remarkable international health research institute located in Dhaka, Bangladesh: the International Centre for Diarrhoeal Disease Research in Bangladesh (ICDDR,B). With an annual budget of US $\$ 12$ million provided by the Government of Bangladesh and by international donors, this institution has done much of the seminal work on the development and evaluation of ORS.
Improved treatment for children with diarrhea is a high priority in Bangladesh. Improved treatments would be expected if sufficient effort and resources are invested in research to turn new mechanistic insights into practical therapeutic measures. Ideally, this effort should be driven by Bangladesh and other developing countries where this particular problem exacts such a toll. To achieve this objective requires the enlistment and nurture of the country's best research minds. Given the costs involved and the resources available for health research in the developing world, a strong international commitment is needed too. How can international involvement be mobilized?

\section{INTERNATIONAL AID FOR HEALTH RESEARCH IN THE DEVELOPING WORLD}

The health research necessary to support progressive health programs is seen by many international donors as a luxury that poor nations cannot afford. It is in all our best interests to work vigorously to change these prevailing views. The Essential National Health Research initiative (17) has been active in presenting a strong position in support of health research in development but it faces an uphill struggle. Two programs involved in health programs in Bangladesh, the $\mathrm{WHO}$ and the Canadian International Development Agency (CIDA), are among many that seem to exemplify current attitudes.

WHO Program for the Control of Diarrheal Diseases: The WHO Program for the Control of Diarrheal Diseases has been one of the higher profile and more productive $\mathrm{WHO}$ programs since its inception in 1980 . With health service and research components, this program has focused its efforts and sizeable budget on the promotion and distribution of ORS (18). The achievements have been impressive: the global distribution of ORS to an estimated $80 \%$ of the population in need and the saving of many lives where the solution was used. However, the impact of this program may be levelling out. Despite a need for the development of a better ORS and drugs to combat diarrhea, research investment by this program has decreased. Between 1984 and 1993 the percentage of total budget invested in research diminished from $41 \%$ to $19 \%$ while the actual amount expended per two years decreased from US\$6.1 to US\$4.1 million (18). The number of funded projects and resultant publications decreased by more than half. On the plus side, in response to concerns over both the ORS formulation now in use and recently published data, the program has taken some action in the past year to assess a revised hyposmolar formulation (19).

CIDA: What is the Canadian response to this major health problem in Bangladesh? Approximately 75\% of Canada's development efforts are administered by CIDA. Until very recently, CIDA has not appeared to emphasize health as a priority (20). Approximately $7 \%$ of its budget can be traced to health programs and of its very large staff, seven have some expertise in the health and nutrition areas. With a new president and a new commitment of at least $25 \%$ of the agency's budget to basic human needs, increased CIDA involvement in health is anticipated. 
Canadian research agencies, including the Medical Research Council of Canada, do not support research abroad, and CIDA has no mandate to support research. That is the job of the International Development Research Centre (21). Recently, it closed its health sciences division, which had been doing a superb job with a very limited budget.

What is to be done? In Bangladesh, as in some other poor nations, the will and talent with which to develop excellence in research are present. What is needed are resources and relationships with established cutting edge scientists and research centres to overcome the isolation and lack of confidence so pervasive in these countries. The objective of these relationships is to establish, in appropriate sites in the developing world, critical masses of scientists capable of indepth studies of health problems relevant to that region. To nurture and retain a core of scientific excellence under the current difficult circumstances requires an infusion of relatively modest resources along with meaningful, long term, nonexploitive international links.

It is difficult to sell health and health research as priorities in development when economic self-interest appears to be driving most aid strategies. The case for health is weakened by a relative lack of successful models that demonstrate the value of foreign aid to the sustenance of a productive health research establishment in a developing region. University links among rich and poor countries (22), private firms (23) and targeted programs (24) are all players in this milieu. Many of these programs have made some valuable contributions but despite the best intentions, when links connect insecure, poor developing institutions with rich, aggressive ones, most often the interests of the wealthy benefit the most through the generation of external grants, publications and academic advancement. Rarely does one find evidence of a sustained beneficial impact on the health research establishment at the developing world end of these relationships. What is required are centres of health research excellence in the developing world where the health problems relevant to that region can be attacked in depth and where developing world scientists will be supported in productive, sustained research careers.

One developing world centre with a critical mass of scientists is the All Indian Institute of Medical Sciences (AIIMS) in New Delhi. With close links to postgraduate educational programs, AIIMS receives meagre financial resources but has the potential to be a driving force for health research in that region. A second model, to which I have already referred, is the ICDDR,B. This large centre, with both hospital- and community-based programs, carries out a range of research programs involving biomedical, behavioural, epidemiological, demographic and environmental scientists, the majority of whom are Bangladeshi (25). The ICDDR,B is funded by many international donor agencies including CIDA and the Government of Bangladesh. Usually about 20 international scientists are involved in collaborative programs and productivity has been relatively high. It is at the ICDDR,B that much of the developmental and evaluative work on ORT was undertaken. With a budget of about US $\$ 12$ million and large clinical services to operate, available funds for research are far from adequate. Furthermore, much of the research in its design and conduct is still driven by international donors.

Nevertheless, the ICDDR,B provides a model of success that warrants the attention of those who plan development strategies. The strategic development of such focused centres in appropriate developing world sites could greatly enhance the opportunities for sustained advances in health status in the poor regions of the world where economic progress cannot be counted on soon and where the horrible burden of disease receives inadequate attention. At present, the world community supports several international agricultural research centres while, as an international health research centre, ICDDR,B is unique.

\section{CONCLUSIONS}

Health warrants a high priority on the development agenda. To succeed, health programs should have a sustainable base in health research that is relevant to and integrated with regional health programs. Taking the example of Bangladesh as a developing country, WHO as a global donor and Canadian CIDA as a national donor, it is clear that the needs are great while the priority assigned to health research by donors is low. An appealing strategy to promote an understanding of and support for health research among donor decisionmakers, most of whom have little background in health, is to invest in a limited number of developing world health research centres focused on relevant issues and integrated with health delivery programs. This modest international investment, if it is to have real impact, should be dedicated to creating sustainable, high quality health research establishments in selected regions of the developing world. These centres would become strong, confident partners in the kinds of international scientific partnership and links needed urgently if progress is to be made with the pressing health problems of the developing world. For those involved in planning such strategies, the model provided by ICDDR,B warrants careful evaluation.

ACKNOWLEDGEMENTS: I am indebted to McGill University, the Foundation of the Montreal Children's Hospital, Les Fonds de la Recherche en Santé du Québec and the International Centre for Diarrhoeal Disease Research, Dhaka, Bangladesh (ICDDR,B) for support during a sabbatical leave spent at the ICDDR,B (1994 to 1995). I thank the many people who tried to educate me about international development in health, among them Demissie Habte, Dilip Mahalanabis, Shamin Ahsan and John Deyell in Dhaka, and Maureen Law and Yves Bergevin in Ottawa.

\section{REFERENCES}

1. Water with sugar and salt. Lancet 1978;ii:300-1. (Edit)

2. World Health Organization. Programme Report 1988-89. Programme for Control of Diarrhoeal Diseases Control. Geneva: World Health Organization.

3. Mahalanabis D, Sack RB, Jacobs B, Mondal A, Thomas J. Use of an oral glucose-electrolyte solution in the treatment of pediatric cholera: a controlled study. J Trop Pediatr 1974;20:82-7. 
4. Hamilton JR, Gall DG, Butler DG, Middleton PJ. Viral gastroenteritis. Recent progress remaining problems. CIBA Foundation Symposium Proceedings, 1976;42:209-22.

5. Sack DA, Chowdhury AMAK, Eusof A, et al. Oral rehydration of rotavirus diarrhoea: a double blind comparison of sucrose with glucose-electrolyte solution. Lancet 1978;ii:280-3.

6. Siddique AK, Salam A, Islam MS, et al. Why treatment centres failed to prevent cholera deaths among Rwandan refugees in Foma, Zaire. Lancet 1995;345:359-61.

7. Hediger MA, Coady MJ, Ikeda TS, Wright EM. Expression cloning and cDNA sequencing of the $\mathrm{Na}^{+} /$glucose cotransporter. Nature 1987;330:379-81.

8. Orlowski J, Kandasamy RA, Shull GE. Molecular cloning of putative members of the $\mathrm{Na}^{+} / \mathrm{H}^{+}$gene family: cDNA cloning, deduced amino acid sequence and mRNA tissue expression of the rat $\mathrm{Na}^{+} / \mathrm{H}^{+}$ exchanger, $\mathrm{NHE}^{-1}$, and two structurally related proteins. J Biol Chem 1992;267:9331-9.

9. Collins JF, Honda T, Knobel S, et al. Molecular cloning, sequencing tissues distribution and functional expression of a $\mathrm{Na}^{+} / \mathrm{H}^{+}$exchanger (NHE-2). Proc Natl Acad Sci USA 1993;90:3938-42.

10. Riordan JR, Rommens JM, Kerem D, et al. Identification of the cystic fibrosis gene: cloning and characterization of complementary DNA. Science 1989;245:1066-73.

11. Hardin JA, Buret A, Meddings JD, Gall DG. Effect of epidermal growth factor on enterocyte brush-border surface area. Am J Physiol 1993;284:G312-8.

12. Powell DW. New paradigms for the pathophysiology of infectious diarrhea. Gastroenterology 1994;106:1705-7.

13. Nocerino A, Iafusco M, Guandalini S. Cholera toxin-induced small intestinal secretion has a secretory effect on the colon of the rat. Gastroenterology 1995;108:34-9.

14. Demographic Surveillance System, early indications. Matlab 1993.
International Centre for Diarrhoeal Disease Research, Bangladesh, Dhaka, 1994.

15. Salway SM, Nasim SM. Levels, trends, causes of mortality in children below 5 years of age in Bangladesh. Findings from a national survey. J Diarrhoeal Dis Res 1994;12:187-93.

16. Progotir P. Progress towards achievements of the goals for the 1990s. Bangladesh Bureau of Statistics, Ministry of Planning, Government of Bangladesh, 1994.

17. Research Capacity Strengthening for Essential National Health Research (ENHR) Council on Health Research for Development. Geneva, 1994.

18. World Health Organization. Programme Reports: 1984-85, 1986-87, 1990-91, 1992-93. Programme for Control of Diarrhoeal Diseases. Geneva: World Health Organization.

19. International Study Group on Reduced-Osmolarity ORS Solutions. Multicentre evaluation of reduced-osmolarity oral rehydration salts solution. Lancet 1995;345:282-5.

20. Canadian International Development Agency (CIDA). Annual Report, 1993. Hull: CIDA, 1994.

21. International Development Research Centre (IDRC). Annual Report, 1993-94. Ottawa: IDRC, 1994.

22. Overseas Development Administration and London School of Hygiene and Tropical Medicine. A partnership in international health. Final report. Joint work programmes 1990-95. London: Overseas Development Administration and London School of Hygiene and Tropical Medicine, 1995.

23. Annual Report, 1993-94. Family planning logistics. Bangladesh: John Snow Inc.

24. Annual Report. Applied Diarrhoeal Disease Research Project (ADDR), 1993.

25. International Centre for Diarrhoeal Disease Research. Annual Report. Bangladesh, 1994. 


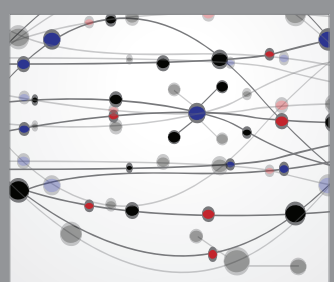

The Scientific World Journal
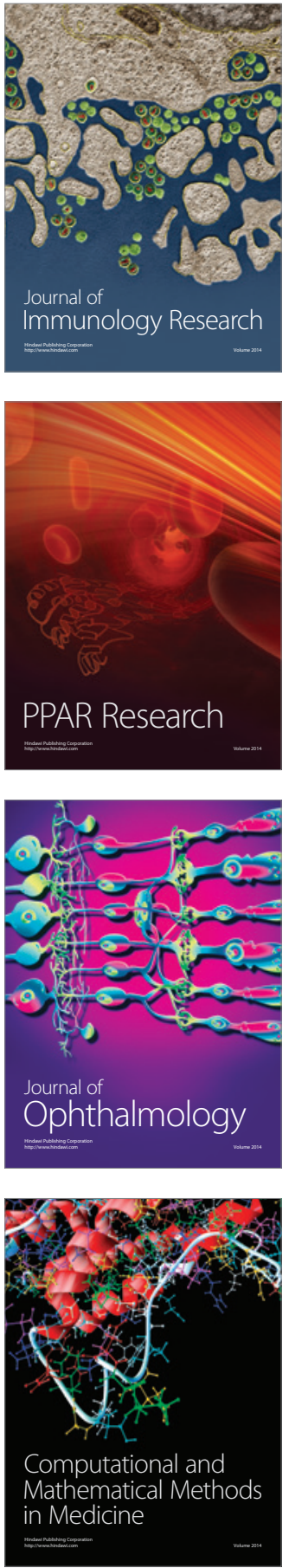

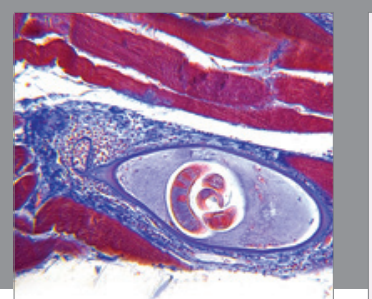

Gastroenterology Research and Practice

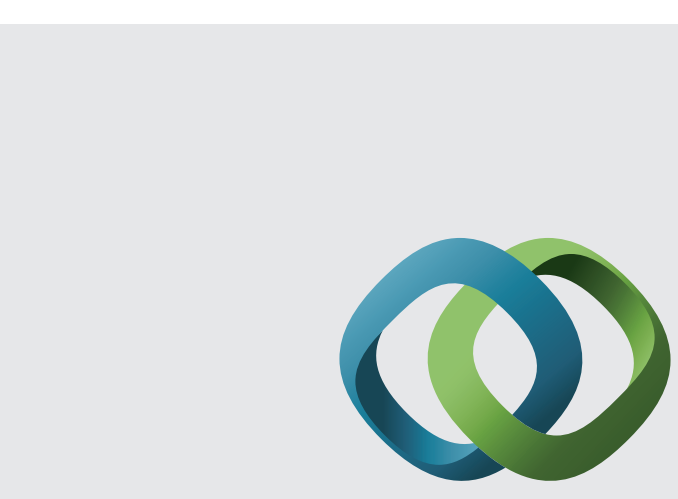

\section{Hindawi}

Submit your manuscripts at

http://www.hindawi.com
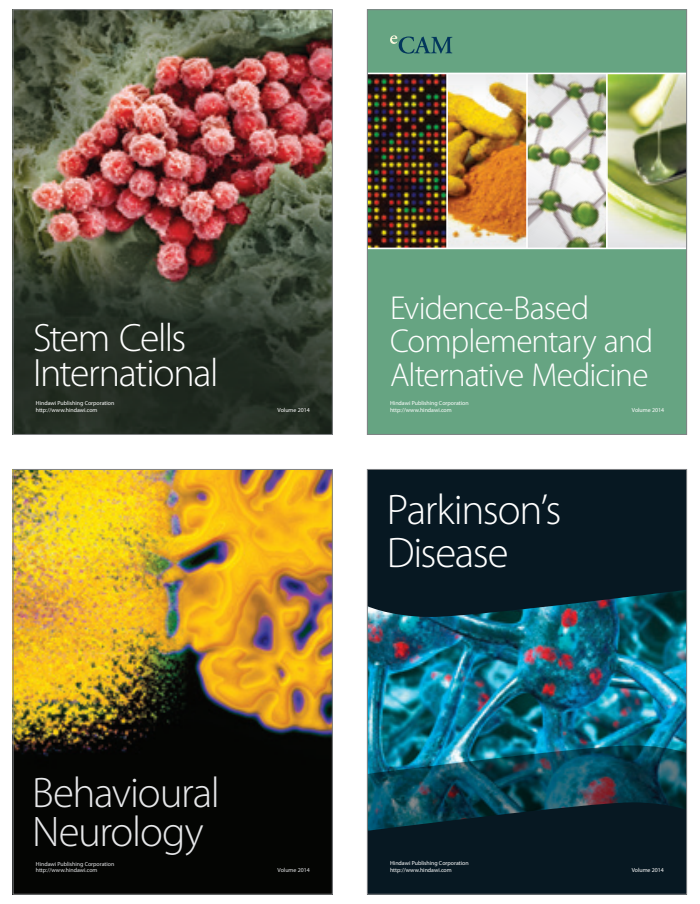
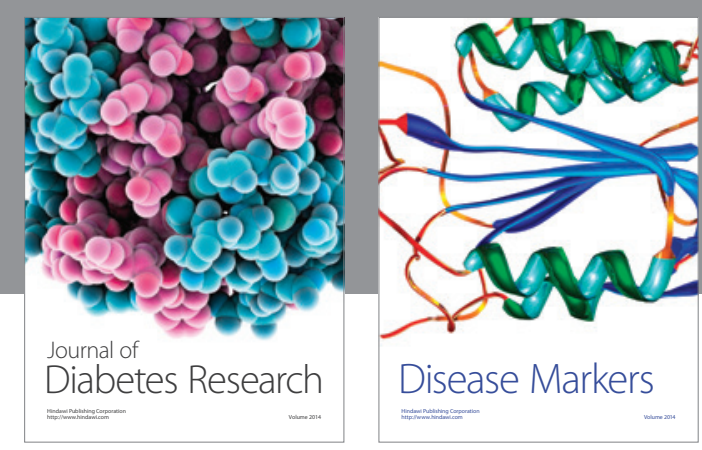

Disease Markers
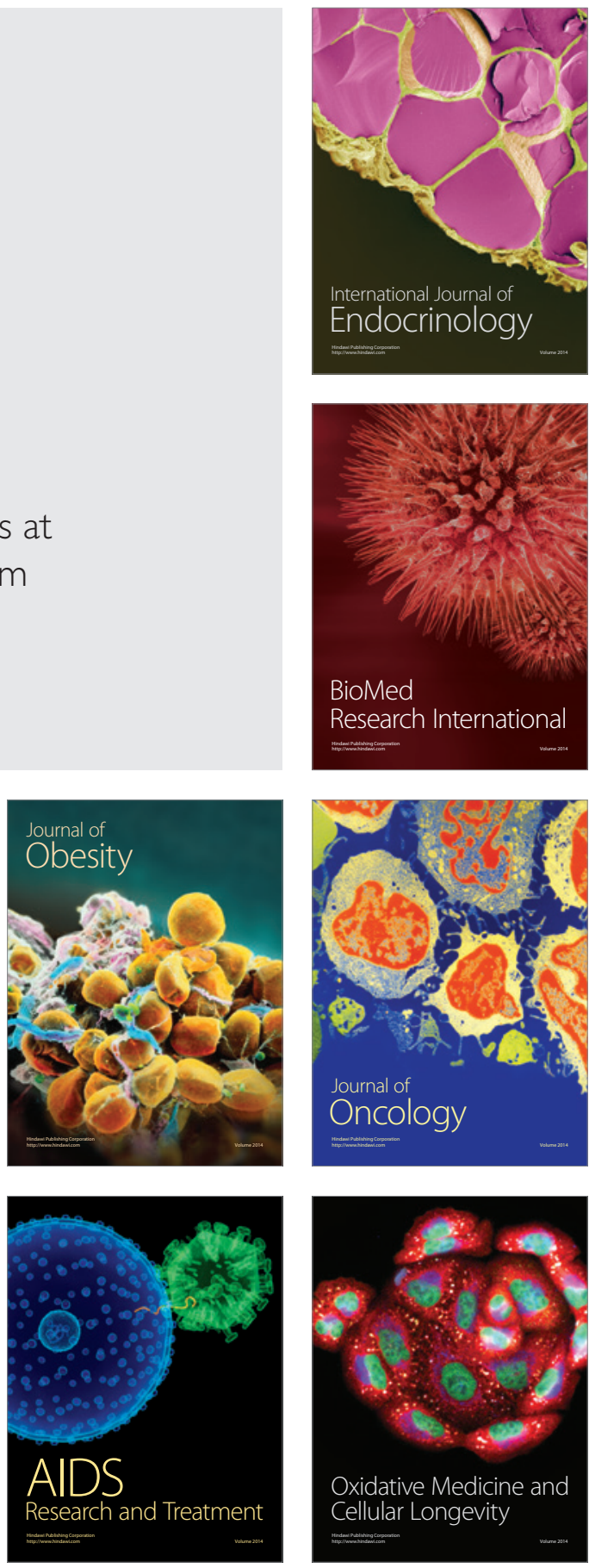